\title{
A World of Difference: The Rich State of Argumentation Theory
}

\section{FRANS H. VAN EEMEREN University of Amsterdam}

Key words: Argumentation, difference of opinion, critical discussion, Radical Argumentativism, Communication and Rhetoric, Formal Dialectics, Pragma-Dialectics, Informal Logic, Formal Analysis of Fallacies.

Abstract: This paper surveys the contributions to the study of argumentation in the two decades since the work of Toulmin and Perelman. Developments include Radical Argumentativism (Anscombre and Ducot), Communication and Rhetoric (American Speech Communication Theory), Informal Logic (Johnson and Blair), Formal Analyses of Fallacies (Woods and Walton), Formal Dialectics (Barth and Krabbe), and Pragma-Dialectics (van Eemeren and Grootendorst).

From the survey it is concluded that argumentation theory has been considerably enriched. If the contributions can be made to converge, a sound basis will be created for developing educational methods for producing, interpreting and evaluating argumentative discourse. Thus, argumentation theory may be instrumental in improving the quality of democracy by furthering a reasonable management of differences of opinion.

\section{Argumentation and democracy}

Speaking in Fulton, Missouri, from the same oaken lectern used by Winston Churchill almost fifty years ago to make his historic "Iron Curtain" speech, the former Soviet leader Mikhail Gorbachev announced on May the $6^{\text {th }} 1992$ "a new era of worldwide democracy." Whether Gorbachev's visionary statement about "democracy" will prove to be accurate is hard to say, but it is certainly true that in the last decade there has been a general turn towards democracy. ${ }^{2}$ In the midseventies transitions to democracy were inaugurated in Southern Europe, in the early eighties in Latin America, and in 1989-during the "Autumn of the People"-in Eastern Europe.

In his book Democracy and the Market, Przeworski (1991) cites a Soviet "anecdote" that nicely describes the situation before these transitions:

A man is distributing leaflets in Red Square. He is stopped by a policeman, who confiscates the leaflets, only to discover that they are blank. "What are you spreading? They are blank. Nothing is written!" the surprised guardian of order exclaims. "Why write?" is the answer. "Everybody knows ...".

It is often observed that in the communist world speech had become a ritual-or otherwise it was dangerous. This has now fundamentally changed. In a period of major change and economic collapse, however, there are inevitably authoritarian temptations. Against this background, the question arises what kind of democracy will be the strongest and the most likely to last.

In Capitalism, Socialism and Democracy, Joseph Schumpeter (1950), the most influential of modern theoreticians of democracy, defines democracy as "a political method, [ . . ] a certain type of institutional arrangement for arriving at political [. . .] decisions" (1943, p. 242). ${ }^{3}$ Ultimately, democracy can be seen as a 
system for dealing with uncertainty by institutionalizing it. The decisive step towards democracy consists in the devolution of power from a group of people to a set of rules, so that conflicts are resolved under established procedures. ${ }^{4}$ Although the outcome of the democratic process depends on what participants do, no single force controls what occurs. Pertinent here is Jules Coleman's observation that "consenting to a process is not the same thing as consenting to the outcomes of the process" $(1989$, p. 197).

Whether we like it or not, compliance with democratic decisions is not selfevident. In order to maintain popular support for the system, a "participatory" style of democracy is required both at the national and at the "lower" levels." In theory, there is always participation in democracy; in practice, however, the main emphasis tends to rely on ensuring the survival of the democratic system and participation is seen as a potential threat to stability. ${ }^{6}$ In order that the participatory method may work, says Schumpeter, "everyone would have to know definitely what he wants to stand for [. . .], a clear and prompt conclusion as to particular issues would have to be derived according to the rules of logical inference [ . . ]-all this the model citizen would have to perform for himself and independently of pressure groups and propaganda" (Schumpeter 1950, pp. 25354). In my opinion, these requirements, however inadequately phrased, are a direct pointer to the basic goals of education in a democratic society. ${ }^{7}$

The democratic system is supposed to offer an institutional framework-a set of rules-for managing differences of opinion and processing disagreement between a broad variety of competing forces. In a context of differences of opinion calling for the justification of standpoints in the light of critical questioning argumentative discussion aimed at resolving the differences plays a crucial role. Argumentative discussion is the main tool for managing democratic processes, and the benefits of such discussion are largely determined by the quality of the argumentation. ${ }^{8}$ When viewed in this perspective, argumentation should be valued as the elixir of life of participatory democracy.

At this juncture, a distinction is to be made between a critical discussion aimed at resolving a difference of opinion and a quasi-discussion which is strictly speaking a monologue merely calculated to gain the audience's consent. ${ }^{9}$ In Western representational democracies, so-called political "discussions" are more often than not a one-way traffic of leaders talking down to their voters; the leaders have the ideas, the voters just applaud them and follow. Only when elections are close, the politicians adjust their positions-in a way which is sometimes embarrassingly opportunistic - to the opinions of their voters. Even then, this adjustment is often by no means the result of an extensive discussion. A democratic system, however, can only justify its name and ensure its continuation by promoting the externalization of differences of opinion and stimulating critical discussion.

It is essential to realise that in a participatory democracy differences of opinion can only be resolved by the use of argumentation in a critical discussion. Education in processing argumentation in a critical discussion is therefore 
indispensable for a democratic society. The education which is required pertains to the students' skills in producing and conducting argumentative discourse as well as to their skills in analyzing and evaluating argumentative discourse. It depends on the state of argumentation theory to which extent this education can be adequately provided.

\section{The state of argumentation theory}

The study of argumentation can demonstrate its practical value by providing a theoretical basis for developing methodical tools for improving argumentative discourse. In this endeavour, both the normative and the descriptive approaches to argumentative discourse which can be found in present-day argumentation theory are necessary, but they need to be integrated in a coherent research programme. ${ }^{10}$ In order to develop adequate procedures for critical discussion and adequate methods for teaching people how to take part in the discussion, analytical insights concerning the requirements of a critical discussion and empirical insights concerning actual discussion processes must be systematically combined."

Argumentative practice can only be methodically improved if the improvement starts from a sound theoretical basis of normative modelling of argumentative discourse grounded on a clear philosophy of critical discussion. Furthermore, the improvement should be based on empirical insight concerning the way in which argumentation is actually conducted founded on accurate descriptions of the factors playing a part in argumentative discourse. In order to know which problems require particular attention in the improvement process, argumentation as it occurs in practice must subsequently be systematically analyzed from the perspective of a critical discussion, which involves a methodical reconstruction of argumentative discourse in the light of the modeled ideal. In this way, an adequate point of departure is created for developing educational methods for enhancing the quality of argumentative discourse effectively.

Elsewhere I have sketched the various parts of this research programme in some more detail, from the philosophical, the theoretical and the empirical components, via the analytical component, to the practical component. ${ }^{12}$ Some time ago, Grootendorst and I began to carry out this programme, together with other members of our research group at the University of Amsterdam. ${ }^{13}$ In this paper, however, I shall not restrict myself to that enterprise but try to give a broader overview of the "riches" of argumentation theory by describing some recent developments in the study of argumentation.

During the past few years I have been working with Grootendorst, Snoeck Henkemans, Blair, Johnson, Krabbe, Plantin, Walton, Willard, Woods and Zarefsky on a general overview of the state of the art in argumentation theory, which has been published as Fundamentals of Argumentation Theory (1996). This study originates in part with The Study of Argumentation (Irvington, 1984), 
jointly authored by van Eemeren, Grootendorst and Kruiger, an English translation of Argumentatietheorie (1978/1981).14 At the time Argumentatietheorie was written we were not aware of the interesting ideas that were being developed elsewhere in the world, if only because these ideas (like our own) had not yet appeared in print. This unawareness, which was probably mutual, has now been rectified owing to the happy development towards internationalisation in the eighties. Therefore, I am now in the position to mention various contributions that in the last two decades, from different backgrounds and angles, have been made to the development of argumentation theory. I hope that my brief overview will make clear that there is a world of difference between the current state of argumentation theory and the late seventies.

Until the late seventies argumentation theory was dominated by the-still influential-works of Toulmin (1958) and Perelman and Olbrechts-Tyteca (1958/1969). In The Uses of Argument Stephen Toulmin presents a model that describes the constitutive elements of argumentation in their functional relation. In La Nouvelle Rhétorique Chaïm Perelman and his co-author Lucie OlbrechtsTyteca provide an inventory of argumentation techniques that can be effective in convincing or persuading an audience. Both books are an attempt to offer an alternative to formal logic for analyzing argumentation and in both cases this attempt is inspired by the rationality of the non-formal reasoning procedures in law.

Toulmin's and Perelman and Olbrechts-Tyteca's contributions have been a major impetus to the study of argumentation, although the goal they set out to reach has not yet been achieved. In my opinion, this can be blamed partly on neglect of functional, social and dialectical aspects of argumentation as a discourse phenomenon, in spite of the appearances to the contrary. Toulmin's approach does not do justice to the fact that argumentation is a speech act complex which is dependent on the commitments created by the linguistic and situational context of the speech event in which it is embedded. Apart from similar shortcomings, Perelman's "new rhetoric" ignores the interactional aspect of argumentation ensuing from the critical reactions of the interlocutors whose approval is sought. Toulmin's and Perelman's abandonment of logic from the tools for dealing with argumentation has not resulted in an alternative which gives the communicative, interactional and critical features of argumentation their due. ${ }^{\text {is }}$

Much has been done during the last two decades to remedy the drawbacks of Toulmin's and Perelman's theoretical propositions, often by substantially amending or even replacing these propositions in the process. In characterizing some of the new approaches that have been developed I shall restrict myself to Radical Argumentativism, Communication and Rhetoric, Formal Dialectics, Pragma-Dialectics, Informal Logic and the Formal Analysis of Fallacies. These six approaches are more or less representative of the current state of argumentation theory. I shall briefly illustrate them by applying each approach to a simple example. 


\section{The riches of argumentation theory}

At a public meeting, two Dutch politicians are discussing a proposal to legalize abortion. Politician 1 says:

The sanctity of all human life has always been a foremost principle of our Christian Party. It would be to go against that principle if we now went along with the proposal before us to legalize abortion. The members of my Party in this House will therefore vote against the proposal.

Politician 2 responds:

You are right to set such store by the sanctity of human life, but you cannot include a six-week foetus. Speaking as a Liberal, I am amazed by your standpoint. What about the sanctity of the life of the mother who has become pregnant against her will and is unable to give the child the life it has a right to?

In Toulminian terms, the first politician appears to defend the "claim" that abortion should not be legalized, whereas the second politician defends the "claim" that it should. The first politician's "data" consist of the observation that the proposal goes against the avowed principle of his party that all human life is sacred. His "warrant" is that principles are inviolable. The first politician presents the sanctity of human life and the legalization of abortion as contradictory; the implication is that to defend both things would be a logical inconsistency. In Perelmanian terms, this argument can be characterized as "quasi-logical". Although it may be compelling to some, the second politician appears not to be convinced; he takes refuge in a "dissociation" between human life and the existence of a six-week foetus. It is not clear which "field-dependent" criteria should, according to Toulmin, be applied to resolve the difference and the "new rhetoric" offers no procedural tool for resolving it.

\section{Radical Argumentativism}

Since the early seventies, the French linguists Ducrot and Anscombre have been developing a linguistically-oriented approach to argumentative discourse. Because every form of discourse has, in their view, an argumentative aspect, they label their approach Radical Argumentativism. ${ }^{16}$ Ducrot and Anscombre's objective is not to develop norms and criteria for the evaluation of argumentation; their approach is exclusively descriptive: they want to trace the linguistic devices which play a role in the argumentative interpretation of sentences.

According to Ducrot and Anscombre, every piece of discourse contains a dialogue, so that it is always "polyphonic" or "many-voiced". A sentence with a negation, for example, implies a silent dialogue with someone who maintains (or at least believes) the opposite of what is being said in that sentence. In "This wall is not white", for instance, this second "voice" can be revealed by analyzing the sentence as containing two (incompatible) standpoints: (a) "This wall is white" and (b) "Standpoint (a) is incorrect". The opposing predicates, "white" and "not white", suggest different "argumentative principles", comparable to the classical topoi. ${ }^{17}$ Ducrot and Anscombre describe how, depending on the context, a 
specific argumentative "power" and "direction" is given to the discourse by argumentative "operators" and "connectors" such as almost, only, hardly, even, but, at least, still, although, few, a little, by the way, moreover, very, too, no less than, since, because and thus. These operators and connectors indicate which standpoint is being defended.

According to Anscombre and Ducrot, the argumentative orientation given by words like "but" and "because" to the sentences in which they occur predestines these sentences to serve as support for particular types of conclusions rather than others. In our example, their insights can be applied to the use of "but" in the response of the second politician- when he says "You are right to set such store by the sanctity of human life, but you cannot include a six-week foetus". The use of "but" marks an opposition between two opposite implicit conclusions: "Abortion should not be legalised" versus "Abortion should be legalized". The first conclusion is supported by the premise presented in the first conjunct, the second by the premise presented in the second. With a $p$, but $q$-utterance, the speaker indicates that he accepts $p$ at a factual level, but rejects $p$ from an argumentative point of view. Therefore, the conclusion that can be drawn from the second conjunct, "Abortion should be legalized", is the one the arguer wants to endorse.

\section{Communication and Rhetoric}

Over the past few years a powerful revaluation of classical rhetoric has been in progress. This revaluation has not only led to the acknowledgement that nonrhetorically oriented theories of argumentation are saturated with insights from classical rhetoric, but also to a moderation of the sharp opposition between rhetoric and dialectic. Rhetoric, as the study of effective techniques of persuasion, is no longer generally regarded as being incompatible with the critical ideal of dialectical reasonableness. ${ }^{18}$

The study of the rhetorical aspects of argumentation is currently usually undertaken from the perspective of communication. Willard, for one, sees argumentation as a rhetorical form of communication starting from differences of opinion; he considers the interaction between arguments, epistemologically, as a source of human knowledge. Various authors working in the field of (speech) communication have given special attention to the rhetoric of conversational argument, most notably Jackson and Jacobs. ${ }^{19}$ Jackson and Jacobs's analysis of conversational argument is based on empirical knowledge concerning strategic patterns of argumentation.

In our example, traces of a strategic pattern of confrontation can be found in the second politician's reaction: the confronter first isolates and targets an assertion made by the confronted and then questions the confronted in a way that elicits premises which can later be seen to contradict his original claim. Having first established the fact that the sanctity of human life is an important principle for the first politician's party, the second politician subsequently continues his 
strategy by confronting him with an apparent inconsistency in his views: "What about the sanctity of the life of the mother... ?"

\section{Formal Dialectics}

Formal Dialectics, introduced by Barth and Krabbe, builds upon Lorenzen's dialogue logic in developing a formal procedure to check whether a given standpoint can be maintained in the light of certain assumptions. ${ }^{20}$ Reasoning in Formal Dialectics is interpreted as consisting of a dialogue between a "proponent" and an "opponent" of a standpoint who attempt to establish whether the proponent's standpoint can be successfully defended against critical attack by the opponent.

For the defence of the standpoint, the proponent can make use of the opponent's "concessions": statements for which the opponent is prepared to take responsibility and which are to be defended if they come under attack. This exchange may result in a situation in which the opponent is unable to do anything other than assert something that the opponent had attacked earlier in the dialogue, which would benefit the proponent. The proponent attempts to manoeuvre the opponent into this position by cleverly using the opponent's concessions. If the attempt succeeds, the proponent has successfully defended the standpoint, due to the opponent's concessions, hence ex concessis.

Formal dialectics can only be used to analyze real-life argumentation if the reasons put forward by the proponent are-as a set of concessions-added to the opponent's commitments. ${ }^{21}$ This is, more or less, what the second politician can be said to be doing with regard to the first politician's statement concerning the sanctity of human life.

\section{Pragma-Dialectics}

In pragma-dialectics argumentation is seen as a speech act complex with a justificatory or refutatory function in a critical discussion aimed at resolving a difference of opinion between a protagonist who is positively committed to the standpoint at issue and an antagonist who is doubtful or has a contrary standpoint. The pragma-dialectical discussion procedure for critical discussion proposed by Grootendorst and myself covers all speech acts performed in all stages of argumentative discourse aimed at resolving a difference. ${ }^{22}$ The rules of the procedure prevent disturbing moves, such as those traditionally known as "fallacies", from interfering with the resolution process. ${ }^{23}$

In a pragma-dialectical analysis of the example, the arguments are first reconstructed in such a way that it becomes clear what the positions of the arguers are, which arguments they have advanced for their standpoints, and in which way their argumentation is structured. The first politician's argumentation is fairly straightforward, but the second politician's reaction requires a considerable amount of reconstruction. For one thing, he does not explicitly state his standpoint. Since his argumentation reacts against the first politician's standpoint 
that abortion should not be legalized, we may take it that he defends the opposite standpoint.

The second politician's first reason, contradicting the validity of the first politician's objection, is that a six-week foetus is not comprised in the principle of the sanctity of human life. Why not, he does not explicitly say; presumably, he thinks that a six-year old foetus cannot be seen as a living human being. His second reason is presented by way of a rhetorical question. The premise involved can be reconstructed as "A woman who has become pregnant against her will and is unable to provide for her child should have the right to end her pregnancy".

How is this premise connected to the standpoint that abortion should be legalized? Which unexpressed premise is understood to fill the gap between the (reconstructed) explicit premise and the standpoint? According to pragmadialectics, the reconstruction of an unexpressed premise requires an analysis at two levels. At the logical level it must first be examined whether the incomplete argument can be completed in such a way that it becomes valid. In the example, this can be achieved by adding the following premise to the argument: "If a woman who has become pregnant against her will and who is unable to provide for her child should have the right to end her pregnancy, then abortion should be legalized". At the pragmatic level it must then be determined whether this "logical minimum" can be transformed into a more informative "pragmatic optimum" by making use of contextual or other pragmatic data. In this case, the unexpressed premise can, in view of the second politician's liberal stance expressed in the preceding sentence, be generalized without ascribing any unwarranted commitments to the speaker by making use of the common background knowledge that the Dutch Liberals are staunch legalists. The unexpressed premise can now be justifiably reconstructed as "A right can only be exercised if it is legalized".

\section{Informal Logic}

Although the name may suggest otherwise, Informal Logic is not a new kind of logic. As it has been developed in North America, it is a normative approach to argumentation in everyday language that is broader than formal logic. The informal logicians' objective is to develop norms, criteria and procedures for the analysis, evaluation and construction of arguments.

The problems for which solutions are sought are, among others, how to analyze argumentation structures, how to classify argumentation schemes, how to evaluate argumentation and how to identify fallacies. Blair and Johnson, leading protagonists of Informal Logic, argue that the premises for a conclusion must satisfy three criteria: "relevance", "sufficiency", and "acceptability" (RSA). ${ }^{24}$ With acceptability the question is whether the premises are true, probable or otherwise reliable; with relevance, whether there is an adequate relation between the contents of the premises and the conclusion; with sufficiency, whether the premises provide enough evidence for the conclusion. 
In our example, the second politician appears to be alluding to each of these criteria in his reaction. He explicitly indicates that he accepts the premise conceming the sanctity of human life. However, he rejects this premise as irrelevant for the conclusion that abortion should be legalized, because he thinks that a six-week foetus cannot be seen as a living human being. Also, he does not consider the premise to provide sufficient support for the conclusion. This is clear from his argument, cloaked in a rhetorical question, that the principle of the sanctity of human life is applied too rigidly when the practical and social consequences for mother and child are overlooked.

\section{Formal Analysis of Fallacies}

Woods and Walton set out in the seventies to meet the challenge entailed in Hamblin's Fallacies to replace the so-called Standard Treatment of the fallacies by a more adequate formal approach. ${ }^{25}$ The Woods and Walton approach, which is rather difficult to characterize briefly, starts from their general methodological conviction that fallacies can be usefully analyzed using the structures and the theoretical vocabulary of various logical systems. In their opinion, successful analyses of at least a great many fallacies will have features that qualify those analyses as "formal" in some sense.

Woods and Walton tend to organize the many fallacies they have recognized into three grades of "formality". First, there are formal fallacies in the strict sense. At the next grade of formality come fallacies such as the fallacies of ambiguity whose commission is, in part, made explicable by reference to logical forms. Much more prominently realized in their work, for example in their analysis of petitio principii, is a third grade of formality pertaining to the fallacies which are formally analyzable by employing the concepts, the technical vocabulary or the formal structures of a system of logic or other sort of formal theory, but not in ways that compel the employment of logical forms in the analysis.

Like Hamblin, Woods and Walton leave it open that there could be several kinds of framework of this type. Their approach can be therefore classified as "pluralistic". Since the context of dialogue of an argument is brought to bear in its evaluation, the Woods-Walton approach is also dialectical. Although the context should in theory be always describable as a structure of dialogue where the moves, locations and commitments and other factors determining the dialogue exchange are defined in a formal way, in practice Woods and Walton admit many other contexts. The theoretical importance they attach to characterizing fallacies in different contexts of ordinary argument is exemplified by their fondness for Case Studies.

If the analysis of the example were to take place along the lines set out by Woods and Walton, it might be possible to accuse the second politician of the fallacy of equivocation. By means of a "contextual shift", the second politician applies the expression "sanctity of life" to the life of the mother, thus using it in a 
different way than the first politician. Rather than meaning that every human being has a right to life, "sanctity of life" now means that all human beings have a right to a "good" life and to arrange their own life accordingly. By equivocating these two meanings, the second politician affects his argument to be sound.

There are still other approaches to argumentation than I have discussed which might have been equally worth mentioning. One of them is Problematology, developed by Meyer in the early eighties as an argumentation model for solving philosophical problems. ${ }^{26}$ Among the others are the various theoretical approaches influenced by Habermas. Kopperschmidt's normative approach to argumentation, for one, combines insights from classical rhetoric, speech act theory, and text linguistics with Habermas's theory. ${ }^{27}$ Natural Logic, the descriptive theory of argumentation developed by Grize, Borel and others, also deserves mentioning. ${ }^{28}$ It is designed to expose the "logic" of everyday argumentative discourse in political addresses, policy statements, and advertisements, without assuming any a priori normative concepts such as "truth" and "validity". ${ }^{29}$ Most other approaches, however, are less influential or more limited in scope than the ones I have discussed and some self-restraint was called for.

\section{Conclusion}

While we are living in a world of difference and there is a world of difference in the various approaches to these differences in the study of argumentation, it should by now be clear that in a much more positive sense of the same expression there also is a world of difference between the state of argumentation theory today and two decades ago. We can, without much exaggeration, speak of "the rich state of argumentation theory". The riches of argumentation theory appear to be such that if they are made to converge an adequate theoretical basis can be created for developing educational methods for improving the quality of argumentative discourse in the various institutional and non-institutional contexts of democracy.

Since democracy requires a realistic understanding of the importance, norms and obstacles of critical discussion, education in argumentation needs to stimulate a critical awareness of the problems involved in producing, interpreting and evaluating argumentative discourse. This cannot be achieved by enforcing imitation of formal procedures upon the students. Instead of teaching drills, education in argumentation should concentrate on promoting a fundamental reflection on the justification of standpoints leading to a genuine appreciation of differences.

\footnotetext{
'De Volkskrant, May 7, 1992.
}

${ }^{2}$ The first part of this paper is based on the author's keynote speech at the Conference on "The role of argumentation in democratic change" in Venice, June 3, 1992. 
${ }^{3}$ Conspicuously, modem theory of democracy is presented as "value-free". Carole Pateman (1990) is right, however, in observing that the normative content of the theory reflects the view that Anglo-Saxon Westerners are living in the "ideal" democratic system. It is even implied that this system includes a set of standards or criteria by which a political system may be judged "democratic".

${ }^{4}$ Bachrach considers systematic rules of procedure to be a necessary condition for calling a country's political method "democratic" (1967: 18-20).

"A high degree of participation is a necessary condition for any living democracy. For the survival of democracy in Eastern Europe, where tough economic and social measures are to be taken, participation is a prerequisite, but participation in democracy is also indispensable for solving the problems of the West.

${ }^{6}$ In western representational democracies limited participation (and even apathy) are often believed to have a positive function for the maintenance of the system by cushioning the shock of disagreement, adjustment and change.

${ }^{7}$ The classical ideal of democracy is, according to Davis (1964:29), to have all the decisions made by "rational and active and informed democratic man", but Berelson et alia rightly observe that "certain requirements commonly assumed for the successful operation of democracy are not met by the behaviour of the "average citizen" (1954: 307). Classical theoreticians of democracy, such as Rousseau and Mill, therefore stressed the need for better education,

${ }^{8}$ Argumentation is by definition a response to (real or projected) doubts, opposition, objections or counterclaims. Its structure and justificatory (or refutatory) design are attuned to resolve a (potential) difference of opinion. This functional view of argument departs from a strictly formal view in which the underlying rationale is ignored.

${ }^{9}$ In the latter case, the discourse is just rhetorical-in the narrowest sense of unidirectional persuasion. If the discourse is an open methodical exchange of views aimed at finding out together which views are acceptable, the discourse is dialectical. Human interaction is not always automatically resolution-oriented. Often people do not enter into discussion willing to subject their standpoints to critical scrutiny. Not only is their willingness constrained by existing inequalities in power relations, lack of resources and skills, but also are they sometimes heavily vested in certain standpoints or positions. This is why van Eemeren and Grootendorst, following Barth and Krabbe (1982), emphasize the importance of the fulfilment of certain preconditions of "higher order". Cf. van Eemeren, Grootendorst, Jackson and Jacobs (1993: 30-36).

10 Normative argumentation theorists, whose roots are often in logic or philosophy, are primarily interested in establishing criteria for sound argumentation. Cf. Biro and Siegel (1992). Descriptive argumentation theorists want to describe, often within the framework of discourse analysis or rhetoric, the ways in which arguers make use of argumentation to convince others of their views. Cf. Willard (1989).

11 It goes without saying that analytical and empirical insights concerning modes of argumentative discourse where either the sender or the addressee is silent are to be included in this dialogical perspective.

${ }^{12}$ See van Eemeren (1994).

${ }^{13}$ See van Eemeren and Grootendorst $(1984,1992)$ and van Eemeren, Grootendorst, Jackson, and Jacobs (1993), and van Eemeren and Grootendorst (Eds., 1994).

is This book was republished in 1987 as the Handbook of Argumentation Theory.

15 For a more detailed review of Toulmin's and Perelman's contributions to the study of argumentation, see van Eemeren et al. (1996, Ch. 4 and 5). 
${ }^{16}$ Ducrot and Anscombre believe that "argumentativity" is a general feature of all language use rather than a special characteristic of a specific mode of discourse. The outlines of their approach have been presented in Ducrot $(1980,1984)$, and Anscombre and Ducrot (1983, 1989). Only lately has their theory become somewhat better known outside the Frenchspeaking world. Cf. Noblke (1992), Zagar (1995) and for a general overview van Eemeren et al. (1996: Ch. 11).

${ }^{17}$ An application of a topos to this example would be: "The whiter the wall, the less it needs repainting", or the converse: "The less white the wall is, the more it needs repainting". In the context of these topoi it can become clear that with "This wall is not white" a conclusion is defended such as "The wall should be repainted". According to Ducrot and Anscombre, this shows that in a certain context all words can have a certain argumentative value.

18 There are also authors who maintain that there are fundamental differences between a rhetorical and a dialectical conception of rationality or reasonableness. In so far as they are rhetoricians, they refuse to regard the first as inferior to the second. In my opinion, rhetoric need not be at odds with a critical ideal of reasonableness: empirical knowledge of effective persuasion techniques can be seen as a prerequisite for bringing about communicatively adequate dialectics. Rhetorical moves which violate the critical ideal can be detected in the analysis of argumentative discourse.

19 See, for instance, Jackson and Jacobs $(1980,1981)$ and Jacobs and Jackson $(1981,1982$, 1983, 1989).

${ }^{20}$ For an exposition of formal dialectics, see Barth and Krabbe (1982); for Lorenzen's dialogic logic, see Lorenzen and Lorenz (1978).

${ }^{21}$ This kind of discussion differs fundamentally from ordinary argumentative practice. It assumes a starting-point in which one of the parties has presented reasons in defence of a standpoint and then decides to examine together with the other party whether this standpoint can be maintained in the light of these reasons. In other words, the parties initiate a procedure to check whether the standpoint can be concluded from the premises that have been presented. Having finished their argumentative discussion, it can of course be very useful if the parties in a difference of opinion would decide to initiate such a logical testing procedure.

${ }^{22}$ The pragma-dialectical discussion procedure is introduced in van Eemeren and Grootendorst (1984). In van Eemeren and Grootendorst (1992: 208-209) the procedure is summarized in ten basic rules, the "Ten Commandments" of critical discussion.

${ }^{23}$ See van Eemeren and Grootendorst (1992: 102-207).

${ }^{24}$ See Johnson and Blair (1977/1994) and Blair and Johnson (1987).

${ }^{25}$ The Woods-Walton approach is exhibited in a series of jointly-authored articles which were published in the period 1972-1982 (collected in Woods and Walton, 1989) and in numbers of independently authored articles and books published during this time and thereafter. Woods and Walton also explained their approach of the fallacies in a textbook (1982).

${ }^{26}$ See Meyer (1982a, 1982b, 1986a, 1986b).

${ }^{27}$ See Kopperschmidt $(1978,1980,1989)$.

${ }^{28}$ See Grize (1982), Borel, Grize and Miéville (1983), Borel (1989) and Maier (Ed., 1989).

${ }^{29}$ Argumentation is, of course, studied from still a great many other backgrounds and angles. Various important contributions can, for instance, be found in Benoit, Hample and Benoit (Eds., 1992). 


\section{Bibliography}

Anscombre, J.-C., and O. Ducrot (1983) L'Argumentation dans la langue. Lì̀ge: Pierre Mardaga.

. (1989) "Argumentativity and informativity," in M. Meyer, ed., From Metaphysics to Rhetoric. Dordrecht: Kluwer, pp. 71-87.

Bachrach, P. (1967) The Theory of Democratic Elitism: A Critique. Boston: Little and Brown.

Barth, E. M., and E. C. W. Krabbe (1982) From Axiom to Dialogue: A Philosophical Study of Logics and Argumentation. Berlin/New York: Walter de Gruyter.

Benoit, W. L., D. Hample, and P. J. Benoit, eds., (1992) Readings in Argumentation. Berlin/New York: Foris Publications, PDA 11.

Berelson, B. R., P. F. Lazarsfeld, and W. N. McPhee (1954) Voting. Chicago: University of Chicago Press.

Biro, J., and H. Siegel (1992) "Normativity, Argumentation and an Epistemic Theory of Fallacies," in F. H. van Eemeren, R. Grootendorst, J. A. Blair \& Ch. A. Willard, eds., Argumentation Illuminated. Amsterdam: Sic Sat 1, pp. 85-103.

Blair, J. A. \& R. H. Johnson (1987) "Argumentation as Dialectical," Argumentation 1: 4156.

Borel, M.-J. (1989) "Norms in Argumentation and Natural Logic," in R. Maier, ed., Norms in Argumentation. Proceedings of the Conference on Norms 1988. Dordrecht: Foris, PDA 8, 33-48.

Borel, M.-J., J.-B. Grize, and D. Miéville (1983) Essai de logique naturelle. Bern/Frankfurt/New York: Peter Lang.

Coleman, J. (1989) "Rationality and the Justification of Democracy," in G. Brennan \& L.E. Lomansky, eds., Politics and Process. Cambridge: Cambridge University Press.

Davis, L. (1964) "The Cost of Realism: Contemporary Restatements of Democracy," Western Political Quarterly XV1I: 37-46.

Ducrot, O. (1980) Les échelles argumentatives. Paris: Minuit.

Ducrot, O. (1984) Le dire et le dit. Paris: Minuit.

Eemeren, F. H. van (1994) "The Study of Argumentation as Normative Pragmatics," in F.H. van Eemeren \& R. Grootendorst, eds., Studies in Pragma-dialectics. Amsterdam, Sic Sat 4, pp. 3-8.

Eemeren, F. H. van and R. Grootendorst (1984) Speech Acts in Argumentative Discussions: A Theoretical Model for the Analysis of Discussions Directed towards Solving Conflicts of Opinion. Dordrecht/Cinnaminson: Foris Publications, PDA 1.

Eemeren, F. H, van and R. Grootendorst (1992) Argumentation, Communication, and Fallacies. Hillsdale (N.J.): Lawrence Erlbaum.

Eemeren, F. H. van and R. Grootendorst, eds., (1994) Studies in Pragma-dialectics. Amsterdam: Sic Sat 4.

Eemeren, F. H. van, R. Grootendorst, S. Jackson, and S. Jacobs (1993) Reconstructing Argumentative Discourse. Tuscaloosa/London: University of Alabama Press.

Eerneren, F. H. van, R. Grootendorst, and T. Kruiger (1978/81) Argumentatietheorie. Utrecht/Antwerpen: Het Spectrum. Aula 613. English translation (1984): The Study of Argumentation. New York: Irvington. Republished (1987) as Handbook of Argumentation Theory. Dordrecht/Cinnaminson: Foris, 
Eemeren, F. H. van, R. Grootendorst, A. F. Snoeck Henkemans, J. A. Blair, R. H. Johnson, E. C. W. Krabbe, Ch. Plantin, D. N. Walton, Ch. A. Willard, J. Woods, and D. Zarefsky (1996) Fundamentals of Argumentation Theory: A Handbook of Historical Backgrounds and Contemporary Developments. Mahwah (N.J.): Lawrence Erlbaum.

Grize, J.-B. (1982) De la logique à l'argumentation. Genève: Librairie Droz.

Jackson, S., and S. Jacobs (1980) "Of Conversational Argument: Pragmatic Bases for the Enthymeme," Quarterly Journal of Speech 66: 251-265.

Jackson, S., and S. Jacobs (1981) "The Collaborative Production of Proposals in Conversational Argument and Persuasion: A Study of Disagreement Regulation," Journal of the American Forensic Association 18: 77-90.

Jacobs, S., and S. Jackson (1981) "Argument as a Natural Category: The Routine Grounds for Arguing in Natural Conversation," Western Journal of Speech Communication 45: 118-132.

Jacobs, S., and S. Jackson (1982) "Conversational Argument: A Discourse Analytic Approach," in J. R. Cox and Ch. A. Willard, eds., Advances in Argumentation Theory and Research. Carbondale, IL: Southern Illinois University Press, pp. 205-237.

Jacobs, S., and S. Jackson (1983) "Strategy and Structure in Conversational Influence Attempts," Communication Monographs 50: 285-304.

Jacobs, S, and S. Jackson (1989) "Building a Model of Conversational Argument," in B. Dervin, L. Grossberg, B. J. O'Keefe, and $E_{x}$ Wartella, eds, Rethinking Communication. Beverly Hills: Sage Publications, pp. 153-171.

Johnson, R. H., and J. A. Blair (1977/94) Logical Self-defense. Toronto: McGraw-Hill.

Kopperschmidt, J. (1978) Das Prinzip vernünftiger Rede. Stuttgart, etc.: Kohlhammer.

Kopperschmidt, J. (1980) Argumentation. Stuttgart: Kohlhammer.

Kopperschmidt, J. (1989) Methodik der Argumentationsanalyse. Stuttgart: FrommannHolzboog.

Lorenzen, P., and K. Lorenz (1978) Dialogische Logik. Darmstadt: Wissenschaftliche Buchgesellschaft.

Maier, R., ed., (1989) Norms in Argumentation: Proceedings of the Conference on Norms 1988. Dordrecht: Foris, PDA 8.

Meyer, M. (1982a) Logique, langage et argumentation. Paris: Hachette.

Meyer, M. (1982b) "Argumentation in the Light of a Theory of Questioning," Philosophy \& Rhetoric 15: 81-103.

Meyer, M. (1986a) De la problématologie. Philosophie, science et langage. Brussels: Pierre Mardaga.

Meyer, M. (1986b) From Logic to Rhetoric (Translation of Logique, langage et argumentation. Paris: Hachette, 1982). Pragmatics and beyond VII: 3. Amsterdam: John Benjamins.

Nølke, H. (1992) "Semantic Constraints on Argumentation: From Polyphonic Microstructure to Argumentative Macro-structure," in F. H. van Eemeren, R. Grootendorst, J. A. Blair \& Ch. A. Willard, eds,, Argumentation Illuminated. Amsterdam: Sic Sat 1, pp. 189-200.

Pateman, C. (1990) Participation and Democratic Theory. Cambridge: Cambridge University Press.

Perelman, Ch. \& L. Olbrechts-Tyteca (1958/69) La nouvelle rhétorique. Traité de l'argumentation. Paris: Presses Universitaires de France. English translation: The New 
Rhetoric. A Treatise on Argumentation. Notre Dame/London: University of Notre Dame Press.

Przeworski, A. (1991) Democracy and the Market.Political and Economic Reforms in Eastern Europe and Latin America. Cambridge: Cambridge University Press.

Schumpeter, J. A. (1950) Capitalism, Socialism and Democracy. New York: Harper Bros. Toulmin, S. E. (1958) The Uses of Argument. Cambridge: Cambridge University Press.

Willard, Ch. A. (1989) A Theory of Argumentation. TuscaloosalLondon: University of Alabama Press.

Woods, J., and D. N. Walton (1982) Argument: The Logic of the Fallacies. Toronto: McGraw-Hill Ryerson.

Woods, J., and D. N. Walton (1989) Fallacies: Selected Papers, 1972-1982. Dordrecht/Providence: Foris Publications, PDA 9.

Zagar, 1. Z. (1995) "Argumentation in Language Opposed to Argumentation with Language: Some Problems," in F. H. van Eemeren, R. Grootendorst, J. A. Blair and Ch. A. Willard eds., Reconstruction and Application: Proceedings of the Third International Conference on Argumentation. Vol. III. Amsterdam: Sic Sat 5, pp. 20015.

FRANS H. VAN EEMEREN VAKGROEP TALLBEHEERSING UNIVERSITIEIT VAN AMSTERDAM SPUISTRAAT 134, 1012 VB AMSTERDAM THE NETHERLANDS 